\title{
History, Power, and the Providential Order in the Neo-Latin Drama Theodoricus by Nicolaus Vernulaeus ${ }^{1}$
}

\begin{abstract}
This paper aims at presenting the way in which Nicolaus Vernulaeus (1583-1649) combines in his Neo-Latin drama Theodoricus. Rex Italiae (Theodoric, the King of Italy) history and current public affairs with the philosophico-theological view of the Divine governance over the world. The title character is juxtaposed with other chief men in the late Roman state: Boethius, Symmachus, and John. The author of the article considers the role of history in this play and the way in which the idea of Providence is engaged in the description of one episode taken from antiquity. In Vernulaeus' text ancient history becomes an implicit costume which serves as ethical enhancement of its viewer or reader, by means such as making allusions to the current political situation.
\end{abstract}

\section{Introduction}

Nicolaus Vernulaeus (Nicolas de Vernulz, 1583-1649), famous humanist ${ }^{2}$ of the Low Countries, authored works covering such fields as the theory of rhetoric, pol-

${ }^{1}$ I would like to acknowledge Mr. Colin J. Nicholson, as well as my friends Anna and Paul for improving this paper's English. I am also grateful to the anonymous reviewers of Neerlandica Wratislaviensia for their helpful hints. It is a recasted and broadened version of my speech presented at the conference "(Re)-Visions of History in Language and Fiction", Nicolaus Copernicus University, Toruń 2010.

${ }^{2}$ See: Valerius Andreas, Bibliotheca Belgica de Belgis vita scriptisq[ue] clariss[imis], praemissa Topographica Belgii totius seu Germaniae inferioris descriptione, Lovanii 1643, pp. 699-701; Jacob A. Worp, Geschiedenis van het drama en van het tooneel in Nederland, Deel 1, Rotterdam 1970, pp. 227-228; Charles H. Lohr, "Renaissance Latin Aristotle Commentaries: Authors So-Z", Renaissance Quarterly, Vol. 35, No. 2 (1982), pp. 216-217; Joost Depuydt, Nicolaus Vernulaeus (1583-1649): een bio-bibliografische studie, diss. lic., thesis advisor: Jan Roegiers, Leuven 1991; Pierre Delsaerdt, De bibliotheek van Nicolaus Vernulaeus. Een facsimile van de boekveilingcatalogus vit 1649, Wildert 2005; Erik De Bom, Geleerden en politiek: de politieke ideeën van Justus Lipsius in de vroegmoderne Nederlanden, Hilversum 2011, pp. 309-328 ff.; Jan Bloemendal, 
itics, and history. This professor of rhetoric at the University of Louvain, known also as a representative of the early modern academic theatre ${ }^{3}$, was keenly concerned about the benefits that may be taken from the past. The past events seemed to him to be the best background of his fourteen Latin tragedies ${ }^{4}$, in which we may observe strong didactic inclinations and parallels with the current political and social affairs ${ }^{5}$. Moreover, Vernulaeus' plays were conceived as an exemplification of easily broken fortune and its ups and downs, especially with reference to rulers. According to his biographer, Vernulaeus puts stress on the application of history to the working knowledge of civil life and to the ability of government policy ${ }^{6}$.

Among Vernulaeus' tragedies there are ones dealing with the plots deriving from antiquity: Crispus, Divus Eustachius, Maximus, and Theodoricus. Roman history ${ }^{7}$, one alternative to Vernulaeus' present life, serves as a costume to Vernulaeus for expressing his beliefs on the present state and policy. In my paper I would like to investigate how Vernulaeus joins together the episode of ancient history with the philosophico-theological conception of the providential order in the world. By this conception I understand here one of the main assumptions of Neo-Stoic thought, that means the idea of purposefulness and God's guidance of the world, the construct investigated from the point of view of the ancient philoso-

\footnotetext{
"Neo-Latin Drama in the Low Countries", [in:] Neo-Latin Drama and Theatre in Early Modern Europe, eds. Jan Bloemendal, Howard B. Norland, Leiden and Boston 2013, pp. 349-350, 363-364.

${ }^{3}$ Next to Vernulaeus, the humanistic theatre in the Low Countries had great authors of tragedies such as George Holonius, Michael Hoyerus, Jacob Cornelius Lummenaeus à Marca, Daniel Heinsius, and Hugo Grotius, to name only a few, as referred by James A. Parente Jr. in Religious Drama and the Humanist Tradition: Christian Theater in Germany and in the Netherlands 1500 1680, Leiden 1987; see also: Jozef IJsewijn, "Annales theatri Belgo-Latini: Inventory of Latin Theatre from the Low Countries", [in:] idem, Humanism in the Low Countries. A Collection of Studies Selected and Edited by Gilbert Tournoy, "Supplementa Humanistica Lovaniensia" XL, Leuven: Leuven University Press, 2015, p. 231.

${ }^{4}$ See: Andrzej Borowski, Iter Polono-Belgo-Ollandicum. Cultural and Literary Relationships between the Commonwealth of Poland and the Netherlands in the 16th and 17th centuries, Krakow 2007, pp. 88-102.

5 See: Louis Schuster, "History of the Louvain Academic Theater", [in:] idem, "Henry VIII". A Neo-Latin Drama by Nicolaus Vernulaeus, translated and edited with a "History of the Louvain Academic Theater", Austin 1964, pp. 28-29.

${ }^{6}$ Historiam vero veterem potissimum ita tractare consuevit, ut simul et ad Politicam scientiam artemque regendi atque administrandi Rempublicam viam sterneret. See: Henning Witte, Vita clarissimi viri Domini Nicolai Vernulaei, Sanctae Theologiae Licentiati, Historiographi Regii ac Cesaraei, et Eloquentiae Professoris Publici in Academia Lovaniensi, [in:] idem, Memoriae philosophorum, oratorum, poetarum, historicorum et philologorum nostri seculi clarissimorum renovatae decas quinta, Francofurti 1679, p. 91.

${ }^{7}$ In the early modern period, next to exploiting the history in the dramatic narrations, there is also rather a more veiled way, the Biblical narration. It is present in the tragedies of some Jesuits following Seneca, as Carolus Malapertus with his Sedecias or Jacobus Libenius presenting the life of the Old Testament Joseph as an area for operating of Divine Providence. See: Jan Bloemendal, op. cit., p. 355.
} 
phy modified under the influence of Christianity. In his Theodoricus Vernulaeus reinterprets the history of Boethius' condemnation, going beyond the version that we know from the late ancient masterpiece, the Consolatio Philosophiae. I am going to show how the early modern author of the tragedy makes use of the ancient plot so that it could serve as a costume both for his contemporary times and as an exemplification of his beliefs. In this context, there is not only the moralistic significance of Theodoric (as it was in many Neo-Latin, especially Jesuit tragedies), but also its political fixing. The choice of the late-antique personages as main figures of the tragedy is a safe way to articulate both admonishments and postulates towards the actors of the present public discourse.

To give a response to the posed question about the way of interpreting history and power according to the idea of Providence I, among others, am going to present the content of the tragedy, characterize the figures of Theodoric and Boethius, and to indicate the linguistic traces of the idea of providential order in the text. I will also outline the political and denominational context in which the tragedy Theodoricus was written and staged. There is also an ethical dimension of introducing the main characters of all his plays: picturing the explicit examples of good or bad conduct. These dramas were a means of forming and confirming good behaviour (mores), as Martin Lunaecenius, theologian and professor in Louvain, wrote in his censorial assessment at the end of the edition in the volume covering ten dramas, titled Tragoediae decem, published in 1631. This opinion was repeated in the posthumous collective edition of all fourteen of Vernulaeus' tragedies in $1656^{8}$.

Theodoricus was published for the first time in 1623. The title page of the first edition of this tragedy contains information about staging the play: we are informed that the tragedy was performed on $7^{\text {th }}$ October 1622 in the Collegium Porcense ${ }^{9}$, Louvain. Since the academy of Louvain was one of the most prominent Catholic centres in the Low Countries in the age of the denominational maelstroms, we can observe a strong confessional involvement in Vernulaeus' tragedies.

\section{The historical background of the plot}

Before staging Theodoricus, Vernulaeus had just authored dramas covering the themes of martyrdom, denominational conflicts, and the relations between the authority and the individual (Gorcomienses, 1610; Divus Eustachius, 1612; Divus

${ }^{8}$ See: Jan Bloemendal, op. cit., p. 350.

${ }^{9}$ N. Vernulaeus, Theodoricus. Tragoedia exhibita ludis remigialibus in Collegio Porcensi, Lovanii, nonis Octobris 1622, typis H. Hastenii, 1623. Collegium Porcense was one of the colleges at the Old University of Louvain and Vernulaeus was a teacher there. 
Stanislaus, 1618) ${ }^{10}$. As we may notice, Vernulaeus creates martyrs as the title characters of these three plays. In the next tragedy, Theodoricus, the eponymous personage is the king of East Goths in Italy (ruling in the years 471-526), Theodoric the Great, who is set to serve as an example of moral collapse of the former superb monarch and the forerunner of the final fall of the author's confessional dissenters. Referring to the events of the $6^{\text {th }}$ century enables Vernulaeus to speak about his own times without mentioning directly the specific contemporary circumstances.

Vernulaeus takes the plot from the story of the famous late ancient philosopher, Boethius, and depicts the events from the last years of Theodoric's reign, when Boethius fell under suspicion of machination in favour of the emperor Justin. This ruler of the Eastern Roman Empire - contrary to Arian Theodoric was a Catholic, and as such he respected the leadership of Pope John I, later accused of treason. The accusers also incriminated Boethius in being involved with a collusion against Theodoric. The times shortly before his execution in 524 or in 525 Boethius spent imprisoned in writing his most famous work, De consolatione philosophiae (Consolation of Philosophy) ${ }^{11}$, in which he discussed the question of evil, fortuity and God's Providence. Also Boethius' father-in-law, Symmachus, was accused of treason and eventually condemned to death. In 526 Theodoric ordered to incarcerate Pope John I who came back from his journey to Constantinople. He soon died and was found a saint. The sanctity of condemned Boethius seemed to be confirmed by the ancient tradition, among others, with the calendar of Pavia in which there is mentioned Saint Severinus who has been identified with this famous Roman aristocrat ${ }^{12}$. Vernulaeus seems to follow this version of Boethius' history.

${ }^{10}$ See: Louis Schuster, op. cit., p. 11; Andrzej Borowski, "W sprawie powiązań literackich polsko-niderlandzkich w XVI-XVII wieku (O tragedii Divus Stanislaus M. Vernulaeusa i jej związku z Historia Kromera)", Zeszyty Naukowe Uniwersytetu Jagiellońskiego. Prace Historycznoliterackie, 17 (1970), pp. 83-100.

11 The widely read Consolatio Philosophiae has been an inspiration and source of comfort for a great number of humanists and artists. Due to his — as has been believed — unfair damnation and spiritual quandaries, Boethius generated interest also in Baroque, when the fragility of human fate on the one hand and the sumptuousness of temporal life on the other, were inseparably intertwined. See: Danute Schanzer, "The Death of Boethius and the Consolation of Philosophy”, „Hermes”, 112 (1984), pp. 352-366. About the way in which some humanists regarded the most popular Boethius' work see: Lodi Nauta, "Some Aspects of Boethius' Consolatio philosophiae in the Renaissance", [in:] Boèce ou la chaîne des saviors: actes du colloque international de la fondation Singer-Polignac, ed. Alain Galonnier, Louvain and Paris 2003, pp. 767-778.

${ }^{12}$ See: Henry Chadwick, Boethius. The Consolation of Music, Logic, and Philosophy, Oxford 1990, p. 68. What is interesting, however, is the fact that in Martyrologium Romanum elaborated by Caesar Baronius, under 23 October the bishop of Cologne, Severinus, is mentioned. Let us also remember that from Late Antiquity we have another one overview of Boethius, expressed by his contemporary Maximianus in his third elegy. Although Boethius is called here magnarum scrutator maxime rerum, he is conceived mainly as a consoler of a miserable lover and an advisor rather not 


\section{The storyline and the structure of Theodoricus}

In Vernulaeus' narrative, the plot is in fact limited to no more than several months: it covers the relation about Pope John's visit in Constantinople, the executions of John, Boethius and Symmachus, as well as the death of Theodoric. The action seems to cover several days, during which we observe the king's rapidly growing insanity. In the last act of the play there is also the supernatural order of things, which is beside the earthly life. This tragedy is divided into five acts like the Senecan dramas, which is a typical mode of giving a structure to a Neo-Latin tragedy ${ }^{13}$. The dramatists of the seventeenth century highly regarded Seneca the Philosopher both thanks to his treatises as well as his tragedies ${ }^{14}$.

In contrast to other Vernulaeus' dramas, each act of Theodoricus is proceeded by a brief synopsis of the events presented in that particular part of the play, apart from the general summary at the beginning of the drama. In the first act Theodoric, presented as a presumptuous Arian ruler, gets angry after being informed that Pope John, sent to Constantinople, consecrated some temples in the Roman Catholic rite. The Gothic ruler is mislead that the Byzantine emperor threatens his authority. The king decides to imprison the bishop of Rome, where the latter dies in the glory of martyrdom.

In the second act there is among others a dialogue of personified Revenge (Vindicta) with the apparition of Pope John and an angel. John is not the only victim of Theodoric's anger; the monarch takes pleasure in realizing that John is dead. Due to the letters fabricated by the invidious courtiers, especially Sylvanus, Boethius and Symmachus are accused of treason and also imprisoned. The efforts of two influential personages, Reimerus and Cyprianus, who want to calm down the king are fruitless. Elpidia, the wife of the great philosopher, visits the condemned persons with their two sons.

In the third act there is some hope for setting prisoners free. Elpidia talks with Amalasuntha, Theodoric's daughter, who wants to convince his father to liberate Symmachus and Boethius. Theodoric pretends that he will release the captives,

distinguished by prudishness. See: Joseph Szövérffy, "Maximianus a Satirist?", Harvard Studies in Classical Philology, 72 (1968), pp. 351-367; Anna Maria Wasyl, Genres Rediscovered: Studies in Latin Miniature Epic, Love Elegy, and Epigram of the Romano-barbaric Age, Kraków: Jagiellonian University Press, 2011, pp. 108, 141-145, 244.

13 See Jan Bloemendal, "Neo-Latin Drama", [in:] Brill's Enyclopaedia of Neo-Latin World. Macropaedia, ed. Philip Ford, Jan Bloemendal and Charles Fantazzi, Leiden and Boston 2014, p. $474,478$.

${ }^{14}$ In the preliminaries to some collective edition of early modern dramas published in 1634 Seneca was called "the source and the first man of the Latin tragedians". Latinorum tragicorum fons et princeps. See: Joannes Cnobbarus, Studiosae Iuventuti Typographus, [in:] Selectae PP. Societatis Iesu Tragoediae, Antverpiae 1634, p. 5. See: Jan Bloemendal, "Neo-Latin Drama in the Low Countries", pp. 349, 352. 
although - as we know - he will not keep his word. It is told that Boethius and Symmachus are killed ${ }^{15}$.

In the fourth act we observe Theodoric's developing madness and the action of Vindicta striving toward administering harsh punishment to Theodoric. During the banquet the king, trying to recover himself, recognizes the head of Symmachus as the head of some fish delivered as a meal. Then the events proceed faster. The king's daughter is helpless over the madness of her father. After sudden convulsions Theodoric is brought to bed, where he is more and more strongly tormented by compunction.

Theodoric's death is announced in the fifth act. But that is not the end of the play. Worse things await the king in the afterlife. Although the remorseful monarch begs to be pardoned, he is sentenced by the Divine Justice (Justitia Divina) to endless torture. At the end of the drama we see the poor damned soul of the king. Its desperate monologue follows the utterance of the daemons who remind that the punishment for the soul - eternal death — is immutable. The soul bewails itself and execrates the body as a source of all its miseries leading to the condemnation.

There are several songs of choirs in the play: the angels' choir announcing the death of John (act I), the angels' choir glorifying the death of Boethius (act III) and the death of Symmachus (act III), the choir's song after the death of the Pope (act I) and the ones closing the first, the second, third, and fourth act of the play. The choir's songs reflects the philosophical beliefs of Vernulaeus himself and provide a condemnation of tyranny.

In the tragedy there is no mention about Theodoric's seat, Ravenna. This lack of a definite place is an advantage, thanks to which the play becomes supertemporal and can always refer to the present time.

In Vernulaeus' play the empirical world is intrinsically connected with the supernatural one. That is the reason why next to historical figures such as Theodoric, his daughter Amalasuntha, Pope John, Boethius and his father-in-law Symmachus, there are also such figures as the choir of angels, the apparition of Pope John and other executed persons, as well as the daemons. There are also some allegorical figures, such as Divine Justice and Revenge.

\section{Sources and their creative reusage}

The plot of this play is the result of Vernulaeus' rereading of both the Consolation of Philosophy as well as some of the sixteenth and seventeenth century commen-

15 One can observe the analogy with the construction of Consolatio Philosophiae itself, where in the third book there is a famous poem (number 9) in hexameters (Cons. Phil., III 9, with the incipit: $O$, qui perpetua mundum ratione gubernas), conceived as the most important poem in the whole book. In Vernulaeus' play the deaths of two persecuted and innocent persons are presented as the most evident exemplification of tyrants' fury. 
taries of that work. At the beginning of his play, in the summary, Vernulaeus adduces the authors whom he read for composing Theodoricus. They are the late Antique historians Gregory the Great with his Dialogues (IV 30) and Procopius, and modern authors Caesar Baronius, Julius Martianus Rota, and Carolus Sigonius. In the early modern period, Annales ecclesiastici (Ecclesiastical Annals) written by Baronius was one of the most important sources for Church history. Describing the reign of Theodoric, Baronius emphasizes the king's strong confessional involvement for the Arians. This is also the way in which Vernulaeus describes the Gothic king.

The next source, namely the biography of Boethius by the sixteenth century physician and translator Julius Martianus Rota (we do not know the exact dates of his life) was reprinted in the edition of the Consolation of Philosophy which was published in Antwerp in $1607^{16}$. Its editor Joannes Bernartius was also connected with the University of Louvain. Without doubt Vernulaeus knew this edition. In Boethius' laudatory biography Julius Martianus follows the account of Boethius himself. In addition, he emphasizes the denominational reason of his misfortune, as Vernulaeus does. According to the ancient belief of the inhabitants of Ticinum, the most probable place of Boethius' execution, he was killed by impious persons. This opinion was repeated by Martianus. Carolus Sigonius (1524-1584) in his Histories of the Eastern Empire ${ }^{17}$ calls the condemnation of John, Symmachus, and Boethius "temerity". Procopius of Caesarea writes that Boethius and Symmachus "practiced philosophy and were mindful of justice in a manner surpassed by no other man"18. As per the testimony of Sigonius, retold after the fifth book of the History of the Wars by Procopius, Theodoric regretted his decision; Vernulaeus puts the stress on the fruitlessness of tardy grief. Also another humanist from the University of Louvain, Ericius Puteanus (1574-1646), in his Barbarian Histories depicts the plot of unfair damnation. He regards the king's conscience pangs as a divine retribution ${ }^{19}$.

${ }^{16}$ Anicius Manlius Severinus Boetius, De consolatione philosophiae libri quinque. Iohannes Bernartius recensuit et commentario illustravit, Antverpiae 1607.

${ }^{17}$ Carolus Sigonius, Historiarum de occidentali imperio libri XX [...], Bononiae 1578, book XVI, p. 451.

18 Procopius of Caesarea, History of the Wars: Books 5-6 (Gothic War) V 1, 33, transl. by Henry B. Dewing, New York 2007, p.13.

${ }^{19}$ Ericius Puteanus, Historiae barbaricae libri VI, qui irruptiones barbarorum in Italiam, occasum imperii, et res Insubrum continent. Ad exemplum Flori conscriptae, Antverpiae 1634, p. 21 f: Fortuna velut flamma est, residere solet et novo mox incendio erumpit. Saeva est et ut amplius noceat, decipit. Interea Theodoricus, quamdiu vegetus, bonus quoque fuit: ad ultimum deficiens et tamquam nimia felicitate obrutus, graves annos saevitia et iniustitia foedavit. Symmachum Boëtiumque viros optimos sanctissimosque non contentus Ticinum relegasse, interfecit. Arrianis addictus, pressit orthodoxos, ipsumque pontificem maximum Ravennam evocatum, velut ad terrorem omnium, vinclis, fame, siti, maceravit. While writing about the malady that afflicted Theodoric, Puteanus 
As we can notice, almost every above mentioned historian wanted to impart the moral significance of the related story to the last years of Theodoric's kingship. So does Vernulaeus, since that was the appropriate attitude in the school theatre of Louvain. But Vernulaeus has a creative approach to the historical nuances. For example, in the tragedy Theodoricus, one of the characters who wants to appease the king is Cyprianus. In the Consolatio Philosophiae Boethius himself mentions, however, that Cyprianus was one of the officials who started to accuse him. By reformulating this version, Vernulaeus underlines the individual responsibility of the Gothic king for his anger. Nevertheless, there are two courtiers-sycophants who want to obtain Theodoric's reign. Vernulaeus allocates the deaths of Boethius and Symmachus as if they were almost simultaneous; nonetheless Boethius perished a year or two before his father-in-law.

\section{The tragic conflict of the play}

Resulting from the above presented plot, one of the most important motifs of this play is the conflict between the severe sovereign and innocent individuals who seek the opportunity to freely express their own views. This conflict is put in the Christian historiosophy of Divine governance over the world and the ultimate victory of good. As we can observe the philosophy of history as stated by Vernulaeus is clear: after the vices there is always a punishment and good people are finally awarded a sempiternal prize. That assumption led to the distinct presentation of two antagonistic sides: the audacious Arian king and the unfairly accused people. But what is more, the writer seeks the solution to the iniquity that has been committed. As in many classical tragedies, characters are convinced of the appropriateness of their conduct, whereas the author gives the rightness only to one side of this struggle. There are not, therefore, two equivalent strivings. The tragic conflict portrayed in this play goes on the level of different reasons. One of them is the obedience to the ruler, another one is acting in accordance with the well formed conscience. Of course an individual must be doomed in a scuffle with the ruler when the argument of the power is stronger than the power of the argument. That was the case of John, Boethius, and Symmachus, as we can read in Vernulaeus' tragedy.

The tragic conflict has its roots in two conceptions of authority: the earthly one, represented by Theodoric, and the supernatural, which is embodied by Pope John. Also mentioned is Emperor Justin, who combines these two dimensions: being the ruler of the earthly empire he acts within the supernal intention when he opposes the Arian denomination ${ }^{20}$. The emperor is defined as "powerful" (for-

points out the role of the divine punishment: Deus ingessit hos stimulos, vindex scelerum: et illatae mortis poena tyranno fuit, Nemesi sua exstingui.

${ }^{20}$ [Theodoricus] nunquam Arrianos asseret ritus manu: / Obstabit Aether, Caesar obstabit potens. ("Theodoric will never save with his arm the Arian rites. Heaven will oppose, the powerful emperor will oppose"). See: N. Vernulaeus, Theodoricus rex, [in:] idem, Tragoediae ..., 1656, p. 136. 
tis $)^{21}$ and as a defender of the Christian faith. The authority of Justin has its divine fixing, whereas Theodoric, who was a good king in the past, has lost his moral values and as so his decisions are temerarious and unreasonable. The motif of imperial power seems to be quite important also in the current political context, as we may observe later in this paper.

The author, maybe unintentionally, draws also the irony of history. The king is fixed on the idea of justice and the punishment for treason; however, eventually he receives the "eternal recompense". The main character of the play personalizes - as Vernulaeus suggests - the worst feature of a ruler, lack of restraint. The consequence of bad-tempered behaviour may be seen in the king's defeat. Even the decision of condemnation of three influential citizens is in fact a way of awarding them with a prize which is life with God. It is explained by an Old Man (Senex) in his utterance to the executed Pope: "Therefore, looking down at the Earth, you laugh at the tyrant. He broke his fury on you, being extremely angry, and when he was taking life from you, he gave you enormous joy of eternity"22.

\section{Theodoric's faults and the response of Providence}

There are several causes for the tragic grand finale of Theodoric. His strong anger makes him a miserable effigy, vulnerable to intrigues of his courtiers. We are getting to know Theodoric when he is a corrupted ruler, although he had been a righteous king. He is advised by some of his servants to reject an increasing vexation. Theodoric fails because of disobedience to reason which in the plot of the tragedy is represented as an Old Man and some servant. The king's demeanour is portrayed as a fury. The Latin verb furere - to rage and the noun furor occur to describe demeanour of Theodoric ${ }^{23}$.

On the philosophical level the fault of the king relies in the deflection from the reason counselling temperance, forgiveness, and justness. His devotion to the Arian matter in the Byzantine Empire is, as dramatised by Vernulaeus, a battle in the name of the wrong affair. But the worst cause is his unwillingness to live after death, despite the fact that he is condemned to everlasting life. Even his obsessive ideas and an aimless, belated penitence are not so nagging. The ghostly apparitions of three sentenced people (umbrae interfectorum) seen only by him may be interpreted not only as a symptom of insanity. One should rather understand them as a direct interference of the supernatural world in life on the Earth. We can consider this Vernulaeus play as a discourse on beliefs on eschatological issues and in the posthumous responsibility of deeds done during temporal life. This tragedy mirrors the rigorous morality according to which the wrongdoing cannot remain unpunished. That is the

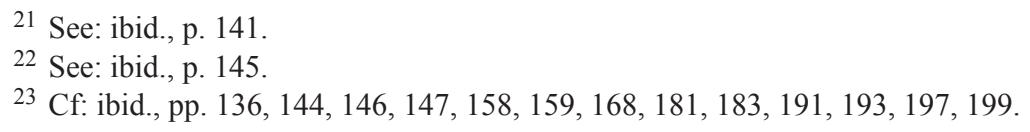


reason why the personified Revenge in the drama demands to give lessons to the barbarian king. In Vernulaeus' play there is Vindicta. She is mitigated by the Justice of God, and in this dramatic work there is no place for mercy, however before the crime there is a chance for Theodoric to regain his senses. In fact, the Divine Justice depicted in Vernulaeus' play resembles that from the Old Testament ${ }^{24}$.

Does Vernulaeus want to induce fear in his readers, the fear of the Divine Providence? It is not an accident nor only a continuation of the former literary tradition that the author uses the metonymy Tonans (Thundering), occurring in Seneca's tragedies and used by the late ancient poet Dracontius. Vernulaeus calls God the Judge ${ }^{25}$, which is an explanation why there is a punishment on Theodoric. If we have responded in the affirmative to the above question, we should also add that Vernulaeus wants his readers to have hope in God's discernments. Vernulaeus avoids using the word providentia in his tragedy, but in his play there are phrases and words which refer directly to the idea of Providence. Let us enumerate such as rerum Arbiter (Overseer of the things) ${ }^{26}$, Numen (God's will; God) ${ }^{27}$, Moderator [...] temporum (Governor of Seasons) ${ }^{28}$, vigiles Numinis oculi (watchful eyes of God) ${ }^{29}$, regum Rex Deus (God, the King of Kings) $)^{30}$, Tonans Vindex (Thundering, the Punisher) ${ }^{31}$, patiens est Tonans, tandem tamen / punit severus (Thundering is patient, but eventually He punishes severely) $)^{32}$, etc.

Putting stress only on the justice would be reduction of God's image, therefore the apparition of John says: "The benevolent Father of the enormous world, you are just, but you are also good" 33 . Vernulaeus suggests that in fact the providential order of the world is an order of goodness, as well as an order of justice. The fate of Theodoric is a simple consequence of his disobedience to God's law. God is the source of the power, He gives the authority to the kings and he puts the mode of human life ${ }^{34}$. There is quite a Byzantine manner of depicting God who in Vernulaeus' play is called by the Pope John: "The Emperor of the heavens, Christ". John continues: "the Father of the Earth / the Governor of the sea"35.

Theodoric destroys the natural order of the world while thinking that his will is the instance superior to any other, including the divine. This bearing may be called hybris, haughtiness, a violation of godly law, which is also one of the crucial terms

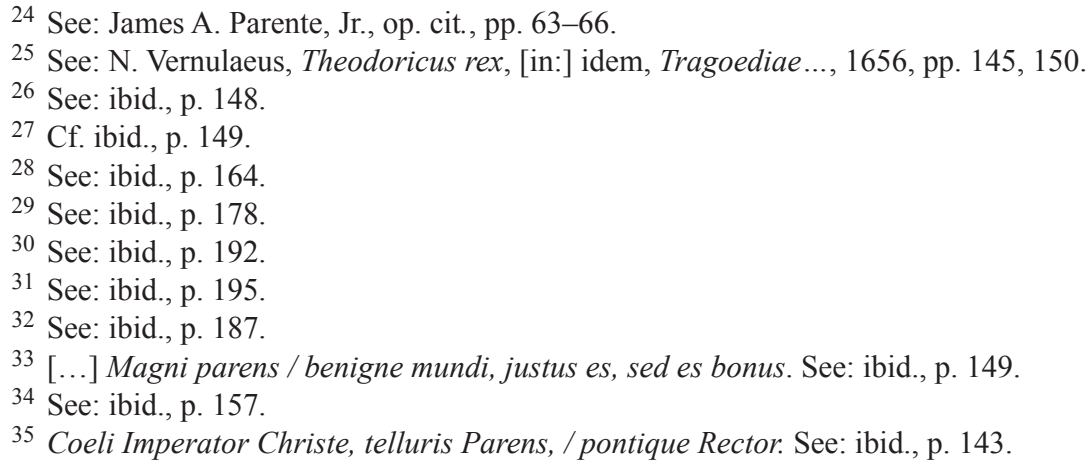


in the ancient Greek tragedies. That is hybris which leads the title character to the final collapse. In case of Theodoric it is in very haughtiness and inadequate self esteem through which he violates both God's and the political order of the world. Theodoric usurps almost unlimited power, even over the Byzantine Empire. The Gothic king boasts: "We conquered the kings, the commanders and the peoples, and Justin himself is afraid of our arms; Rome, the conqueror of nations, adores my feet" 36 . He is even so impudent that he dare to command the Fortune: "This Caesar (O, Fortune, you ought me this name) Justin [...]"37. Theodoric puts his own decisions over the rightness: "If it is not appropriate, that is my will"38. This kind of behaviour is typical for tyrants.

In his play Vernulaeus opposes any kind of tyranny, here exemplified by Theodoric's reigns. His violence of both human and divine law results in his defeat. The Old Man says after the death of Pope John that Theodoric has caused a pain for himself: "This is the thing obtained by the kings where they are tyrants: they excruciate themselves with a long death, when they excruciate others" ${ }^{39}$. The king is characterized by Boethius' wife in her utterance to the king as "false, inhuman, severe, cruel ruler" 40 . Theodoric violates the essential order of the world, while he persecutes Pope John, who is called "the first law of the world" 41 .

God's governance on the Earth cannot be brought together with the audacious tyranny of man and the battle always has only one winner, as Vernulaeus suggests. The paradox and the real tragedy of the Gothic king is that despite the fact that he wants to avoid living by all means since being afflicted with madness, he has to live in torment everlastingly. Vernulaeus finishes his play by the duplication of word "eternity", and Boethius finishes his work with deliberations on eternity and perpetuity. The last words of the Consolatio Philosophiae, speaking about the perspicacious Judge, correspond with the verdict given on Theodoric in Vernulaeus' tragedy. Let us notice that, apart from Vernulaeus who nominally represents the Catholic point of view on Providence, in his Theodoricus the inevitability of the king's collapse puts forward rather Evangelical readings of human freedom. However, Theodoric formally has the opportunity to change his attitude, but as a tragic person in his perseverance in fact he is not able to make a sensible decision. Unlike Seneca, who emphasizes the significance of the personified goddess For-

36 [...] Vicimus reges, duces, / populos et ipse nostra formidatpotens / Justinusarma, gentium victrix meos / pedes adorat Roma". See: ibid., p. 135.

37 Justinus ille ille Caesar (hoc nomenmihi / Fortuna debes). See: ibid., p. 136.

38 [...] Hoc si non decet, / mea est voluntas. See: ibid., p. 139.

39 [...] Hoc reges habent / cum sunt tyranni, morte se longa necant / alios necando. See: ibid., p. 146.

${ }^{40}$ Cf. [...] perfide, immanis, ferox, / truculente princeps. See: ibid., p. 160.

41 [...] prima lex mundi. See: ibid., p. 147. 
tune and the unrelenting Fate, Vernulaeus makes the personal God the final court instance and the supreme authority thanks to which every crime is being punished.

One can be quite disgusted with this unambiguous and severe condemnation of Theodoric. The horrific scenes, however, were favoured in the seventeenth century tragedy, taking delight in the dramatic composition of Seneca the Philosopher, and Vernulaeus was called Seneca Christianus ${ }^{42}$. The natural connection between poetics of Vernulaeus' tragedies and the ancient tragic's plays was also grasped by Vernulaeus' contemporaries. This correlation was emphasised in the poem In tragoedias clarissimi viri Nicolai Vernulaei ${ }^{43}$.

The shocking image and behaviour of Theodoric was not only the esthetical aspect of Vernulaeus' play. This was intended by the dramatist as a way of holding people, especially governors, far away from any form of audaciousness or dissent with the Holy See. While picturing the conflict with both the secular and Arian powers and the representatives of Roman Catholic denomination, Vernulaeus could easily accomplish one of the orator's tasks: to move his addresses, movere. The mode in which the author presents God may be a source of pious fear. The author moves readers or viewers by detailed bloody images, served also as a kind of admonishment in order to maintain the audience in rightness. In Theodoricus by Vernulaeus the scenes of the executions of innocent people are not depicted directly, and in such sense the decorum, one of the rules of ancient Greek tragedies, is observed while relating to the death penalty, rather than in Seneca's plays. The glory of the characters considered as martyrs is contrasted with the terrible despair of damned king surrounded by daemons. By introducing these supernatural figures Vernulaeus seems to try to underline the Counter-Reformation triumphal march towards confessional unity despite the ephemeral — as he believes - successes of the dissenters' movement.

\section{Victorious Boethius: the Neo-Stoic hero}

The special attention given to the cult of saints, typical to the post-Tridentin period, is not accidental. Boethius, as well as Pope John and Symmachus, is presented as one of the saints. In the tragedy by Vernulaeus he is, then, quite different from the Boethius who is known from his own Consolation of Philosophy.

To underline the role of Boethius as a statesman, Vernulaeus omits the literary activities of this "Last Roman". Boethius, elsewhere conceived primarily as an

42 See: James A. Parente, Jr., "The Paganization of Biblical Tragedy: the Dramas of Jacob Cornelius Lummenaeus a Marca (1570-1629)”, Humanistica Lovaniensia, 38 (1989), p. 209; Louis Schuster, op. cit., pp. 31-36; see also: Joanna Pypłacz, The Aesthetics of Senecan Tragedy, Kraków 2010.

${ }^{43}[\ldots]$ si quis Senecam / velit exhiberi [...]. The poem is undersigned by the letters F.I.I. See: N. Vernulaeus, Tragoediae in duos tomos distributae. Editio II, 1656, laef [*5 r]. 
elckerlijc ${ }^{44}$, is depicted by Vernulaeus above all as an innocent victim of a savage tyranny and an example of an excellent bravery up against its rage. One may find an effort towards resolving the vexed question of why blameless people very often suffer from howling injustice. In Vernulaeus' play, however, the theme of suffering of innocent people is a starting point for historiosophic deliberations of God's order in the world and in that sense Boethius still remains a representative of a large group. But Vernulaeus makes him a statuesque figure, deprived of any doubts or grief, a real avatar of Stoic ethics combined with Christian morality. Boethius says: "My mind does not become weaker nor is worried by any fear"45. And there is no space for an assumption of Boethius' apostasy, since he prays before his death. The theory of Divine governance must lead to the full submission to God's will in accordance to the principles of Neo-Stoicism and Boethius acts as a fully obedient to God's discernments. This subordination is one of the marks of real freedom and is compatible with the Stoical indications, since Seneca the Philosopher regarded the service for God (conceived as another name of fate) as libertas. The second premise to speak about Boethius' freedom is being in the state of Stoic apatheia. Although Boethius is imprisoned, in fact he is free, because he does not surrender to any passions nor bad emotions.

Boethius' portrait is depicted in contradistinction to his opponent, Theodoric. The sane and patient conduct of prisoner according to reason (ratio) is contrasted with the insane and intemperate behaviour of the king who falls into rage (furor). We may also make some parallel: reasonableness is a characteristic of Providence (in Greek pronoia, deriving from pro- 'before' and nous - 'reason'), while caprice, unpredictability, and folly characterize Fortune.

In fact also the figure of Theodoric is rather one-dimensional. This imperfection of the king is accentuated by juxtaposition with the figure of an elderly man (Senex), who in Vernulaeus' plays epitomises the voice of common sense and sometimes completes the role of the traditional choir. This character occurs also in Conradinus, Crispus (as Aulicus Senex), Ioanna Darcia vulgo Puella Aurelianensis, Divus Stanislaus (in the last act), and Ottocarus Bohemiae rex (as Senex Astrologus). We can conceive this Old Man as a personification of Neo-Stoical principles. This philosophical movement was developing among others in the Low Countries in the sixteenth and in the seventeenth century. Its representative, Justus Lipsius (1547-1606), advises readers in his treatise On Constancy to liberate themselves from bad affects such as anger. In his Politics Lipsius underlines the role of God's order in the world, but this understanding of Providence cannot be ascribed directly and exclusively to any Christian denomination. Lipsius fol-

${ }^{44}$ See: Henry Chadwick, op. cit., p. 224.

${ }^{45}$ Mens nostra nullo languet aut trepidat metu. See: N. Vernulaeus, Theodoricus rex, [in:] idem, Tragoediae..., 1656, p. 157. 
lows inter alia the philosophical prescriptions of the eclectic stoicism of Seneca, who advises temperance and self control.

In Vernulaeus' tragedy we can notice a desideratum of equanimity or rather we can watch consequences of non-adhering to the postulate of serenity and clemency. Equanimity is one of the main features of Boethius, and also of his fatherof-law and of the Pope. However the term aequanimitas does not occur directly in the text, the message of peace of mind is strongly suggested by the author who is also a teacher. Cautionary remarks that succumbing to anger and other affects entails an unavoidable disaster were addressed to the young people from the University of Louvain. This is more evidence for Neo-Stoical influence on Vernulaeus' tragedy: the vitiation of Theodoric results from his great prosperity and glory. This view on the nature of felicity was represented before not only by Seneca in his philosophical writings, but also by Boethius himself in his Consolation.

But apart from the convergence of ideas there are also some linguistic similarities to the Senecan and Boethian thought. The Latin of the silver age, to which Seneca the Younger belonged, was preferred at the University of Louvain in the seventeenth century. Although Vernulaeus tends to maintain harmony in the language of his tragedy (the anaphor is very often exploited), adages occur, e.g. Theodoric's words: "Commanding is the office of kings, obeying to commands the office of everybody" 46 .

\section{Vernulaeus, Caussinus and others: contact points and divergences}

Next to Seneca's works (in this context Seneca's tragedies are the reference point, as well as his work De ira [On anger]), Vernulaeus must have also came to know about the tragedy titled likewise Theodoricus ${ }^{47}$ by the French Jesuit Nicolaus Caussinus (1583-1651) that was published for the first time in Paris in 1620 in the volume Tragoediae Sacrae together with other dramas: Solyma, Nabuchodonosor, Felicitas and Hermenigildus ${ }^{48}$. The motif of a gory condemnation of the king was also exploited previously by this French author. As far as Caussinus'

46 Jubere regum est: exequi iussa, omnium. See: ibid., p. 137.

${ }^{47}$ Nicholas Caussin, Theodoricus tragoedia, [in:] idem, Tragoediae sacrae, authore P. Nicolao Caussino Trecensi, Societatis Iesu presbytero, Parisiis 1620; see also: George Drew D'Arcy Hocking, A Study of the Tragoediae Sacrae of Father Caussin (1583-1651), Baltimore, Md. 1943, p. $69 \mathrm{f}$.

48 See: Jean-Frédéric Chevalier, "Nicolas Caussin, héritier de Sénèque et de Boèce dans Theodoricus", [in:] Nicolas Caussin: rhétorique et spiritualité à l'époque de Louis XIII: actes du colloque de Troyes (16-17 septembre 2004), ed. Sophie Conte, Berlin-Hamburg-Münster 2007, pp. 79-102; see also: Leicester Bradner, "The Latin Drama of the Renaissance (1340-1640)", Studies in the Renaissance, Vol. 4 (1957), p. 51. Caussinus' Hermenigildus deals also with Arian denomination. 
sources are concerned, he mentions Procopius (De Bello Gothico IV), Martianus, Saint Gregory (Dialogi IV c. 31, 1-4, III 2, 1-3) (9) $^{49}$ and some ancient testimony suggested to him by French Jesuit, Jacque Sirmond (Jacobus Sirmondus). According to the latter testimony, so called Anonymus Valesianus, Boethius with a tied forehead was birched to death. However, assuming this version would not leave much space for the spectacular scene of Boethius' execution which implied a supernatural rough time for Theodoric.

Despite unavoidable similarities between Caussinus and Vernulaeus there are also divergences not only in the naming of the characters, but also in the order of the storylines. The French playwright since the beginning tends to point out the theme of retribution by Nemesis. Her role seems to be crucial for Caussinus' tragedy; she is even mentioned by him as the first character. Vernulaeus puts Theodoric at the top of the list of persons and the punishment - called simply Vindicta, not Nemesis - has a smaller mythological mark. Caussinus follows also the version that Cyprianus and Basilius (the latter not mentioned by Vernulaeus) were the calumniators against Boethius and Symmachus. In Caussinus' Theodoricus some poetry from the Consolatio Philosophiae (cf. I 5; III 12) is included. Also Caussinus keeps the prescriptions of Neo-Stoic principles, which are directly presented as Laus constantiae voiced by the choir. Both tragedies may be also interpreted as an urgent call for real justice of rulers, the virtue that Lipsius postulated in his Politicorum libri ${ }^{50}$. The lack of this quality in sovereign's deeds results in an inevitable intervention of supernatural ones.

Both Caussinus and Vernulaeus take part in the discussion on the providential or fortuitous order of the world. Their literary interpretation, arisen in the post-Tridentin times, gives special attention to the eternal life whose quality depends on the temporal one. Let us notice that the king consistently rejects the possibility of changing his behaviour and abandonment of anger. What is more, in Vernulaeus' relation the king derives pleasure from the intemperate affect. This feature, especially undesirable among rulers, may bring deplorable results for the whole state and society. Political and theological questions permeate very often in the early modern discourse, so that a fine line between what is rooted in objective and transcendental categories and the matters deeply involved in particular and mundane benefit is notoriously intruded. This phenomenon, however common regardless of the denomination, was characterized by Leonardus Lessius SJ in his work On Divine Providence and Immortality of the Soul, which was published in Antwerp in $1613^{51}$.

49 See: Nicholas Caussin, op. cit., leaves a1v-a2v.

${ }^{50}$ See: George H. Tucker, "Justus Lipsius and the Cento form", [in:] (Un)Masking the Realities of Power. Justus Lipsius and the Dynamics of Political Writing in Early Modern Europe, ed. Erik De Bom, Marijke Janssens, Toon Van Houdt and Jan Papy, Leiden-Boston 2011, p. 188.

${ }^{51}$ As Lessius writes, there are some representatives of unorthodox environment who want to assume and adapt their religion beliefs according to the utility of the state. Asserting on not 
It is worth noticing another seventeenth century literary testimony of the discourse on Providence. It is the tragedy kept in a manuscript, written in the first quarter of the seventeenth century, titled Antithemius seu mors peccatoris ${ }^{52}$, ascribed to Jesuit Matthaeus Bembo. The main character is quite similar to Vernulaeus' Theodoric in his perseverance. Another severe ruler seems not to be a good figure of any contemporary sovereign who does not want to follow the canons of playwright's moral standards.

\section{The Thirty Years' War}

The time in which Vernulaeus composed most of his tragedies falls into the period of the Thirty Years' War. Theodoricus was published three years after the Battle of White Mountain. One may be right in asserting that apart from the moralistic and consoling ${ }^{53}$ purports of Theodoricus there are social and political ones. Let us notice that in the Boethian Consolatio Philosophiae the temporal fatherland finally seems not to be as relevant as the eternal one. Boethius, accused of the alleged treason of the Roman state, is guided by Lady Philosophy to give precedence to the supernatural order of the perpetual source of origin, coelum, instead of a political system having its worldly limitations ${ }^{54}$. Allegory, which constitutes a basic key for interpreting the Consolatio Philosophiae by Boethius himself and is so widely present in a Dutch moralistic dramatic compositions ${ }^{55}$ has a weaker effect on Theodoricus. However, there are some personifications which connote the philosophical and political current background of the work. The struggle of the Gothic king with the defenders of the former polity in the changed world after the fall of the Roman Empire is perceived as a good panorama for contemporary

only the presence of the supreme Divinity, Lessius also wants to give proofs of its prudent and purposeful inherence in the world, that is Providence. Besides this meaning of the Latin word providentia Lessius uses it in the sense of human discernment (providentia universalis), which implies the rational capacity of being of control of oneself. See: Leonard Lessius, De providentia numinis et animi imortalitate libri duo [...], Antverpiae: ex officina Plantiniana, apud viduam et filios Io. Moreti, 1613, p. 105. The lack of control of himself is one of the faults of Theodoric in Vernulaeus' play.

52 See: Czesław Hernas, Barok, Warszawa 1998, pp. 210-211.

${ }^{53}$ See: James A. Parente, Religious Drama and the Humanist Tradition: Christian Theatre in Germany and in the Netherlands 1500-1680, Leiden 1987, p. 66.

54 See: Seth Lerer, Boethius and Dialogue. Literaty Method in The Consolation of Philosophy, Princeton, New Jersey, 1985, p. 217. See: Boethius, Cons. Phil., IV m. I: Haec dices, memini, patria est mihi.

55 See: Verena Demoed, “The Morality of Hypocrisy: Gnapheus's Latin Play 'Hypocrisis' and the Lutheran Reformation", [in:] Literary Cultures and Public Opinion in the Low Countries, 1450-1650, ed. Jan Bloemendal, Arjan Van Dixhoorn and Elsa Strietman, Leiden-Boston 2011, pp. 103-105. 
divagation of the state of divided multi-confessional Europe. It is worth noting that Boethius and Symmachus are said to favour the empire ${ }^{56}$. The motif of the coelum may be deciphered also in Vernulaeus' drama, in which the supremacy of the divine law over the political institutions is one of the postulates carried across the work. As Vernulaeus seems to suggest, obedience to the monarch is not unconditional: an individual is equipped with the moral right of nonconformity to unorthodox ruler's prescriptions. Let us notice that the playwright quite often uses the term "emperor", which was mentioned above. Vernulaeus appreciated the archduke of Austria, Albrecht, and his wife, Isabella Clara Eugenia, as well as the Holy Roman Emperors, Ferdinand II and then his son, Ferdinand III. As this professor of eloquence promoted the House of Habsburg (serenissima familia Austri$a c a$ ) involved in the conflict with the dissenters, the Arian king might be a figure of political enemies of the ruling dynasty. We cannot indicate the direct analogy between the Arianism of Theodoric and the Czech people with its strong Unity of the Brethren movement. However, without any doubt perceiving of Habsburg dynasty's enemies might play a significant role in choosing the theme of conflict from the late antiquity. In a straightforward way the opposition against Habsburgs is depicted in Ottocarus, Bohemiae rex seu rebellio contra Rudolphum I, imperatorem, Austriacae familiae conditorem and in Fritlandus ${ }^{57}$. The denominational persecutions of Theodoric's opponents may be juxtaposed with similar acts in contemporary Europe ${ }^{58}$. The motif of martyrdom occurs in several of Vernulaeus' plays $^{59}$. In Theodoricus the author uses the Aesopian language, whereas in some other dramas he speaks in a more open way, e.g. in Henricus octavus. In his Gorcomienses sive fidei exilium the tensions originating from the multi-confessional structure of the continent are depicted by introducing personifications of Catholic faith and three other denominations: Lutheran, Calvinian and Mennonite, supported by the personified Protestant enquiry. A similar kind of allegorisation occurs also in the above mentioned tragedy on the King of England. In Theodoricus we find the clash of civil liberties to act in a conscionable way opposite to the peremptory authority.

56 See: Ovidio Dallera, Cronologia, [in:] Boezio, La consolazione della filosofia, introduzione di Christina Mohrmann, traduzione, cronologia, premessa al testo e note a cura di Ovidio Dallera; testo latino a fronte, Milano 1998, p. 8.

57 See: Edward Lubowski, Wallenstein. Studyum literacko-historyczne, Warszawa 1874; Leicester Bradner, op. cit., p. 52.

58 See: Cicely V. Wedgwood, The Thirty Years War, Norwalk, Connecticut, cop. 1994, pp. $27-28,179$.

59 See: Lynette Muir, Love and Conflict in Medieval Drama. The Plays and Their Legacy, Cambridge 2007, p. 36; Jan Bloemendal, op. cit., pp. 349-350. 


\section{Vernulaeus' message}

Vernulaeus glorifies liberty, also in its political meaning ${ }^{60}$, and he warns that God's Justice will punish anyone who wants to break the natural and supernatural world's order. This order is embodied by the Roman Catholic Church, as Vernulaeus suggests. The denominational conflict, originally interpreted in moral terms, between Theodoric fighting against John, Symmachus, and Boethius, gathers an ageless dimension of struggle for fundamental freedoms of human beings. What Vernulaeus offers us is not a logical discussion as in the Consolation of Philosophy, but direct advice. It should lead both the characters of the play, as well as their actors and readers to the approach towards God's government over the world and human dignity which leaves no space for any questions.

The playwright draws the history of Theodoric, Boethius, Symmachus and Pope John in black-and-white categories. It is not necessarily a weakness of this play, where the instant remedies are more important than methodological divagations leading gradually to discovering the basic regulations of the world's order. Vernulaeus is not obliged to carry on a sublime discourse instead of delivering indispensable and urgent rules.

The historical facts from the times of the reign of Gothic ruler fit perfectly to make use of them in theological, moralistic, and social aspects. Vernulaeus seems to emphasize Theodoric's free choice: the dramatist tends to draw the coherence between God's prescience and human free will. However, Theodoric acts in a deep fury which excludes making reasonable decisions. Secondly, following the interpretation of Theodoric's collapse and the glorification of Boethius and two other martyrs, Vernulaeus finds the guarantee that the contemporary confessional opponents of the Catholicism and Habsburg dynasty, especially nontrinitarians, will be defeated. To emphasize the role of Providence, Vernulaeus introduces in his play the personification of Justice, which becomes the regulator of social matters. The author depicts in a Neo-Stoic mode the leading figures persecuted by the king. This step is a way to confer to the ancient episode the providential costume, in which on Divine command the virtue is finally awarded.

Three condemned persons are representations of heroic personalities so well known from the former Roman and Renaissance tradition of "history as exemplum "61. History was apprehended as an inexhaustible resource of examples of virtue and vice. In Vernulaeus' tragedies once again it becomes a great source of

${ }^{60}$ In Dissertatio de libertate politica, a work composed under the guidance of Vernulaeus, we can read that the real liberty is safeguarded by a good ruler. This work was both praise and apology of the government in the Southern Low Countries. See: Nicolaus Vernulaeus, Dissertatio de libertate politica, habita a rhetoribus academicis in publica schola artium sub Nicolao Vernulaeo, publico eloquentiae professore in Academia Lovaniensi, Lovanii 1628, leaves B4v-B8v.

${ }^{61}$ See: Timothy Hampton, Writing from History. The Rhetoric of Exemplarity in Renaissance Literature, Ithaca and London 1980, p. 21. 
timeless hints and a theatre of divine intervention. In this playwright's attitude there is something more than only preceptorial explanations of the past.

\section{Selected Bibliography}

\section{Primary sources}

Andreas, Valerius, Bibliotheca Belgica de Belgis vita scriptisq[ue] claris[simis], praemissa Topographica Belgii totius seu Germaniae inferioris descriptione, Lovanii: typis Jacobi Zegers, 1643.

Baronius, Caesar, Martyrologium Romanum ad novam kalendarii rationem et ecclesiasticae historiae veritatem restitutum, Gregorii XIII, pontificis maximi iussu editum, Antverpiae: ex officina Plantiniana, apud viduam et filios Ioannis Moreti, 1613.

Boethius, Anicius Manlius Severinus, De consolatione philosophiae libri quinque. Iohannes Bernartius recensuit et commentario illustravit, Antverpiae: ex officina Plantiniana, apud Ioannem Moretum, 1607.

Boethius, Anicius Manlius Severinus, La consolazione della filosofia, introduzione di Christina Mohrmann, traduzione, cronologia, premessa al testo e note a cura di Ovidio Dallera; testo latino a fronte, Milano: Fabri Editori, 1998.

Boethius, Anicius Manlius Severinus, O pocieszeniu, jakie daje filozofia, transl. Gabriela Kurylewicz, Mikołaj Antczak, preface: Agnieszka Kijewska, Kęty: Wydawnictwo Marek Derewiecki, 2006.

Caussinus, Nicolaus, Theodoricus tragoedia, [in:] idem, Tragoediae sacrae, authore P. Nicolao Caussino Trecensi, Societatis Iesu presbytero, Parisiis: ex officina Nivelliana, apud Sebastianum Cramoisy [...], 1620.

Lessius, Leonardus, De providentia numinis et animi immortalitate libri duo adversus atheos et politicos auctore Leonarde Lessio Societatis Iesu s. theologiae professore, Antverpiae: ex officina Plantiniana, apud viduam et filios Io. Moreti, 1613.

Procopius, History of the Wars: Books 5-6 (Gothic War), transl. by Henry Bronson Dewing, New York: Cosimo Classics, 2007.

Puteanus, Ericius, Historiae barbaricae libri VI, qui irruptiones barbarorum in Italiam, occasum imperii et res Insubrum continent. Ad exemplum Flori conscriptae, Antverpiae: typis Joannis Cnobari, 1634.

Selectae PP. Societatis Iesu Tragoediae, Antverpiae: apud Joan. Cnobbarum, 1634.

Sigonius, Carolus, Historiarum de occidentali imperio libri XX, Bononiae: apud Societatem Typographiae Bononiensis, 1578.

Vernulaeus, Nicolaus, Dissertatio de libertate politica, habita a rhetoribus academicis in publica schola artium sub Nicolao Vernulaeo, publico eloquentiae professore in Academia Lovaniensi, Lovanii: typis Philippi Dormalli, 1628.

Vernulaeus, Nicolaus, Theodoricus. Tragoedia, [in:] idem, Tragoediae in duos tomos distributae. Editio II [...], Lovanii: typis Petri Sasseni et Hieronymi Nempaei, 1656, pp. 132-204.

Witte, Henning, Memoriae philosophorum, oratorum, poetarum, historicorum et philologorum nostri seculi clarissimorum renovatae decas quinta, Francofurti apud Martinum Hallervord, typis Johannis Andreae, 1679.

Neerlandica Wratislaviensia 26, 2016

(C) for this edition by CNS 


\section{Secondary sources}

Bark, William, “The Legend of Boethius' Martyrdom”, Speculum, Vol. 21, No. 3 (1946), pp. 312 317.

Bloemendal Jan, "Neo-Latin Drama", [in:] Brill's Enyclopaedia of Neo-Latin World. Macropaedia, ed. Philip Ford, Jan Bloemendal and Charles Fantazzi, Leiden and Boston 2014, pp. 473-484.

Bloemendal Jan, "Neo-Latin Drama in the Low Countries", [in:] Neo-Latin Drama and Theatre in Early Modern Europe, ed. Jan Bloemendal, Howard B. Norland, Leiden and Boston: Brill, 2013, pp. 293-364.

Bloemendal Jan, "Themes and Subjects in Early Modern Latin Plays in the Netherlands", Acta Universitatis Palackianae Olomucensis. Facultas Philosophica. Philologica, 81, 2003, pp. 103-112.

Borowski, Andrzej, Iter Polono-Belgo-Ollandicum. Cultural and Literary Relationships between the Commonwealth of Poland and the Netherlands in the 16th and 17th centuries, Kraków: Księgarnia Akademicka, 2007.

Borowski, Andrzej, "W sprawie powiązań literackich polsko-niderlandzkich w XVI-XVII wieku (O tragedii Divus Stanislaus M. Vernulaeusa i jej związku z Historia Kromera)”, Zeszyty Naukowe Uniwersytetu Jagiellońskiego. Prace Historycznoliterackie, 17 (1970), pp. 83-100.

Bradner, Leicester, "A Check-List of Original Neo-Latin Dramas by Continental Writers Printed before 1650", PMLA, 58 (3), (1943), pp. 621-633.

Bradner, Leicester, "The Latin Drama of the Renaissance (1340-1640)", Studies in the Renaissance, Vol. 4 (1957), pp. 31-54.

Czerenkiewicz, Michał, "Fortuna, fatum i Opatrzność w rozmowie Boecjusza z Filozofią", Nowy Filomata, XII, 2008 (1), pp. 9-21.

Czerenkiewicz, Michał, "Późnorenesansowa refleksja boecjańska Johannesa Bernartiusa", [in:] Glosy filologiczno-filozoficzne na marginesie prac Profesora Juliusza Domańskiego w osiemdziesiata piąta rocznicę Jego urodzin, ed. Jan Kwapisz, Włodzimierz Olszaniec, Warszawa: Instytut Filologii Klasycznej UW, 2012, pp. 313-322.

Chadwick, Henry, Boethius. The Consolation of Music, Logic, and Philosophy, Oxford: Clarendon Press, 1990.

Chevalier, Jean-Frédéric, "Nicolas Caussin, héritier de Sénèque et de Boèce dans Theodoricus", [in:] Nicolas Caussin: rhétorique et spiritualité à l'époque de Louis XIII; actes du colloque de Troyes (16-17 septembre 2004), ed. Sophie Conte, Berlin-Hamburg-Münster: LIT Verlag, 2007, pp. 79-102.

De Bom, Erik, Geleerden en politiek: de politieke ideeën van Justus Lipsius in de vroegmoderne Nederlanden, Hilversum: Verloren, 2011.

Delsaerdt, Pierre, De bibliotheek van Nicolaus Vernulaeus. Een facsimile van de boekveilingcatalogus vit 1649, Wildert: Carbolineum Pers, 2005.

Demoed, Verena, "The Morality of Hypocrisy: Gnapheus's Latin Play 'Hypocrisis' and the Lutheran Reformation", [in:] Literary Cultures and Public Opinion in the Low Countries, 1450-1650, ed. Jan Bloemendal, Arjan Van Dixhoorn, and Elsa Strietman, Leiden-Boston: Brill, 2011.

Depuydt, Joost, Nicolaus Vernulaeus (1583-1649): een bio-bibliografische studie, Leuven: KUL. Fa-culteit letteren en wijsbegeerte. Departement geschiedenis, 1991, diss. lic., thesis advisor: Jan Roegiers.

Grund, Gary R., "Tragedy", [in:] The Oxford Handbook of Neo-Latin, ed. Sarah Knight and Stefan Tilg, Oxford: Oxford University Press, 2015, pp. 103-117.

Hampton, Timothy, Writing from History. The Rhetoric of Exemplarity in Renaissance Literature, Ithaca and London: Cornell University Press, 1980.

Hernas, Czesław, Barok, Warszawa: PWN, 1998.

Neerlandica Wratislaviensia 26, 2016

(C) for this edition by CNS 
Hocking, George Drew D'Arcy, A Study of the Tragoediae Sacrae of Father Caussin (1583-1651), Baltimore, Md.: Johns Hopkins Press, 1943.

IJsewijn, Jozef, "Annales theatri Belgo-Latini: Inventory of Latin Theatre from the Low Countries", [in:] idem, Humanism in the Low Countries. A Collection of Studies Selected and Edited by Gilbert Tournoy, "Supplementa Humanistica Lovaniensia" XL, Leuven: Leuven University Press, 2015, pp. 221-235.

Kerrigan, John, "Revenge Tragedy Revisited: Politics, Providence and Drama", 1649-1683, The Seventeenth Century, XII, No. 2, 1997, pp. 207-229.

Konst, Jan, Fortuna, Fatum en Providentia Dei in de Nederlandse tragedie 1600-1720, Hilversum: Uitgeverij Verloren, 2003.

Lerer, Seth, Boethius and Dialogue. Literary Method in The Consolation of Philosophy, Princeton, New Jersey: Princeton University Press, 1985.

Lohr, Charles H., "Renaissance Latin Aristotle Commentaries: Authors So-Z”, Renaissance Quarterly, Vol. 35, No. 2 (1982), pp. 164-256.

Lubowski, Edward, Wallenstein. Studyum literacko-historyczne, Warszawa: Skład Główny w Księgarni Gebethnera i Wolffa, 1874.

Muir, Lynette, Love and Conflict in Medieval Drama. The Plays and Their Legacy, Cambridge: Cambridge University Press, 2007.

Nauta, Lodi, "Some Aspects of Boethius' Consolatio philosophiae in the Renaissance", [in:] Boèce ou la chaîne des savoirs. Actes du colloque international de la fondation Singer-Polignac, ed. Alain Galonnier, préface de Roshdi Rashed; introduction de Pierre Magnard, Louvain and Paris: Peeters, 2003, pp. 767-778.

Parente Jr., James A., Religious Drama and the Humanist Tradition: Christian Theater in Germany and in the Netherlands 1500-1680, Leiden: Brill, 1987.

Parente Jr., James A., "The Paganization of Biblical Tragedy: the Dramas of Jacob Cornelius Lummenaeus à Marca (1570-1629)", Humanistica Lovaniensia, 38 (1989), pp. 209-237.

Patch, Howard R. "The Beginnings of the Legend of Boethius", Speculum, Vol. 22, No. 3 (Jul., 1947), pp. 443-445.

Pypłacz, Joanna, The Aesthetics of Senecan Tragedy, Kraków: Księgarnia Akademicka, 2010.

Schanzer, Danute, "The Death of Boethius and the Consolation of Philosophy", Hermes, 112 (1984), pp. 352-366.

Schuster, Louis, Henry VIII. A Neo-Latin Drama by Nicolaus Vernulaeus, translated and edited with a History of the Louvain Academic Theater, Austin: University of Texas Press, 1964.

Szövérffy, Joseph, “Maximianus a Satirist?”, Harvard Studies in Classical Philology, 72 (1968), pp. 351-367.

Tucker, George Hugo, "Justus Lipsius and the Cento form", [in:] (Un)Masking the Realities of Power. Justus Lipsius and the Dynamics of Political Writing in Early Modern Europe, ed. Erik De Bom, Marijke Janssens, Toon Van Houdt and Jan Papy, Leiden-Boston: Brill, 2011, pp. 163-192.

Worp, Jacob Adolf, Geschiedenis van het drama en van het tooneel in Nederland, Deel 1, Rotterdam: Fa. Langelveld, 1970.

Wasyl, Anna Maria, Genres Rediscovered: Studies in Latin Miniature Epic, Love Elegy, and Epigram of the Romano-barbaric Age, Kraków: Jagiellonian University Press, 2011.

Wedgwood Cicely Veronica, The Thirty Years War, Norwalk, Connecticut: The Easton Press, cop. 1994.

Neerlandica Wratislaviensia 26, 2016

(C) for this edition by CNS 